National Water Quality Program

National Water-Quality Assessment Project

\title{
Groundwater Quality in Selected Stream Valley Aquifers, Western United States
}

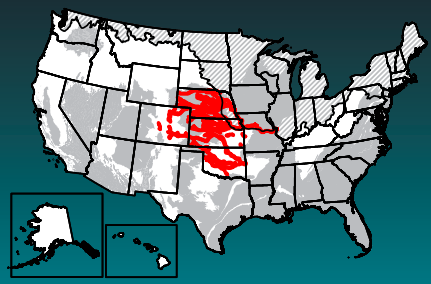

Groundwater provides nearly 50 percent of the Nation's drinking water. To help protect this vital resource, the U.S. Geological Survey (USGS) National Water-Quality Assessment (NAWQA) Project assesses groundwater quality in aquifers that are important sources of drinking water. The Stream Valley aquifers constitute one of the important aquifer systems being evaluated.

\section{Background}

The Stream Valley aquifers sampled for this study underlie an area of about 41,200 square miles in the sedimentary deposits of the Arkansas, Missouri, and Red River drainages. The study area includes parts of Oklahoma, Nebraska, Kansas, Missouri, and Colorado. About 4.5 million people live in the area overlying these aquifers, and about 167 million gallons per day were withdrawn for public supply in these states from Stream Valley aquifers in 2000 (Sargent and others, 2008; Kingsbury and others, 2021). Most of the area overlying the aquifer is undeveloped (54 percent). Agricultural and urban land use make up about 39 and 7 percent of the study area, respectively. Major cities in the study area include Omaha, Nebraska; Kansas City, Missouri; and Tulsa, Oklahoma.

The Stream Valley aquifers are associated with sand and gravel deposited in the valleys of streams or rivers. Typically, the streams are hydraulically connected to the aquifers (Miller and Appel, 1997). Consequently, these aquifers are limited in extent compared to most principal aquifers and usually are only up to a few miles wide, but they can extend over long distances (Ryder, 1996). These aquifers typically are no more than 100 feet thick, but along some of the large rivers may be as much as 160 feet thick (Miller and Appel, 1997). Groundwater in these aquifers usually is unconfined and under water-table conditions; however, locally, confined conditions may exist where coarse-grained sediments are overlain by low permeable silt or clay (Miller and Appel, 1997). Recharge to the aquifer is from infiltration of precipitation and surfacewater drainage from the streams and rivers adjacent to these aquifers (Ryder, 1996; Miller and Appel, 1997).

Groundwater quality in the Stream Valley aquifers was evaluated by sampling 59 publicsupply wells that were randomly distributed in an equal-area grid. Water-quality data collected from wells in a network designed in this way are representative of the spatial distribution of the water quality in the study area (Belitz and others, 2010). Groundwater-quality data from these wells were used to estimate the percentage of the study area with concentrations that are high, moderate, and low with respect to constituent benchmarks. The accuracy of the estimates depends upon the distribution and number of wells, not on the size of the area (Belitz and others, 2010). Wells ranged from about 30 to 200 feet (ft) deep with an average depth of about 85 ft. Samples were collected between June and September of 2018, and the samples were analyzed for a large number of water-quality constituents derived from natural and human sources.

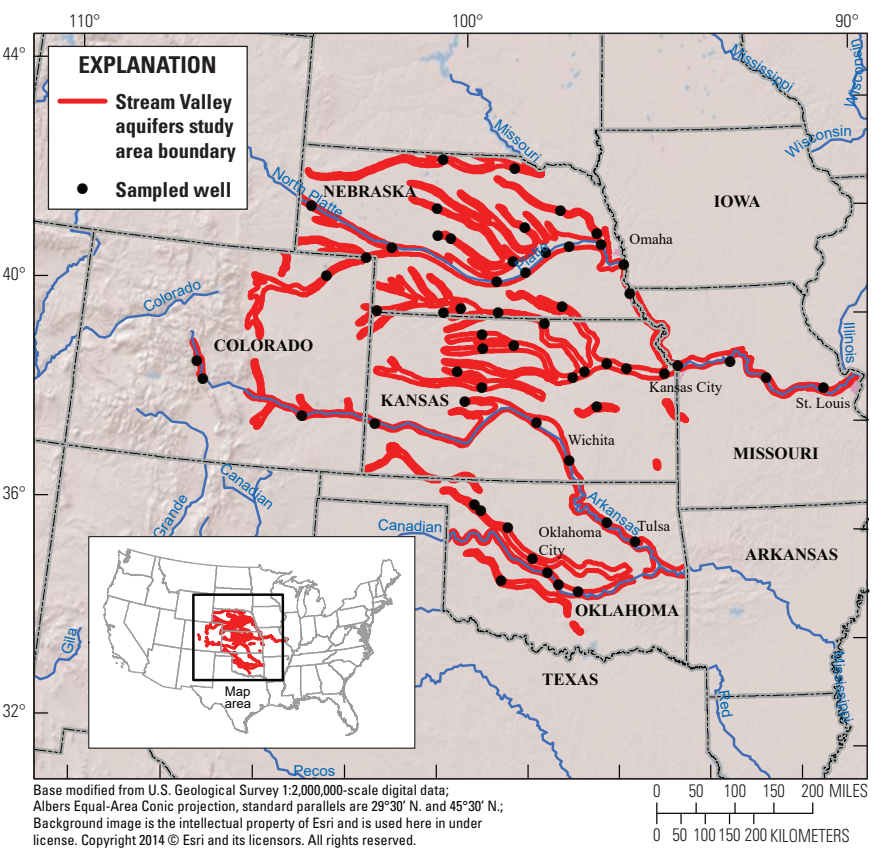

Overview of Water Quality

\section{Inorganic constituents}

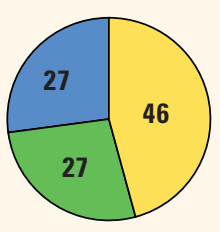

CONSTITUENT CONCENTRATIONS

$\bigcirc$ High $\bigcirc$ Moderate $\bigcirc$ Low or not detected

Values are a percentage of the study area with concentrations in the three specified categories. Percentages might not sum to 100 because of rounding.

Principal Aquifer Studies (Burow and Belitz, 2014) are designed to evaluate untreated groundwater used for public supply. Groundwater quality is assessed by comparing concentrations to benchmarks established for drinking-water quality. Benchmarks and definitions of high, moderate, and low relative concentrations are discussed in the inset box on page 3 .

Many inorganic constituents are present naturally in groundwater; however, concentrations can be affected by human activities. One or more inorganic constituents with human-health benchmarks were present at high concentrations in about 46 percent of the study area and at moderate concentrations in about 27 percent.

Organic constituents are found in products used in the home, business, industry, and agriculture. Organic constituents can enter the environment through normal use, spills, or improper disposal. Organic constituents were detected infrequently, and when detected, concentrations typically were low. One or more organic constituents with humanhealth benchmarks were detected at moderate concentrations in about 8 percent of the study area. 


\section{Results: Groundwater Quality at the Depth Zone Used for Public Supply in the Stream Valley Aquifers}

\section{INORGANIC CONSTITUENTS}

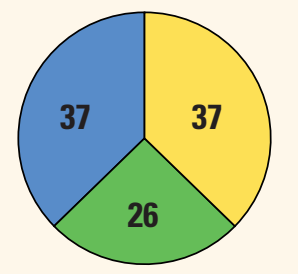

\section{Trace \\ elements and \\ major and minor ions}

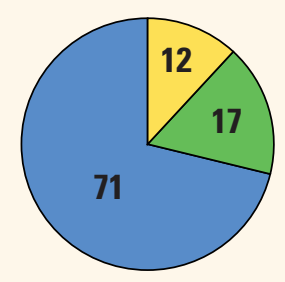

\section{Radioactive constituents}
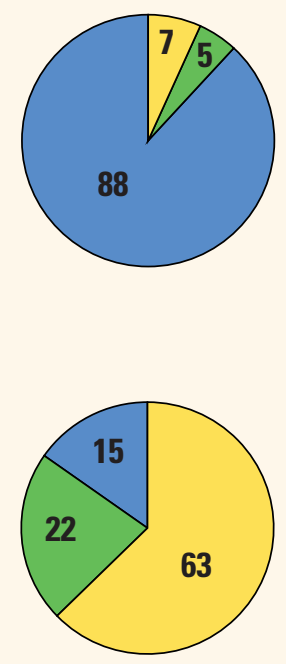

\section{Inorganic Constituents With Human-Health Benchmarks}

Trace elements and major and minor ions are naturally present in the minerals of rocks, soils and sediments, and in the water that comes into contact with those materials. Samples were analyzed for 34 trace elements and major and minor ions, of which 22 have human-health benchmarks (health-based screening level [HBSL] benchmarks were updated in 2018 to include aluminum, cobalt, and iron; Norman and others, 2018). High or moderate concentrations of these constituents were measured in 63 percent of the study area with a total of eight constituents present at elevated concentrations. Manganese was present at high and moderate concentrations in 22 and 8 percent of the study area, respectively. Arsenic was present at high concentrations in 10 percent of the study area and at moderate concentrations in 24 percent.

Radioactivity is the release of energy or energetic particles during the spontaneous decay of unstable atoms, and humans are continuously exposed to small amounts of natural radioactivity. Most of the radioactivity in groundwater comes from the decay of naturally occurring uranium and thorium isotopes. Samples were analyzed for eight radioactive constituents, of which four have human-health benchmarks. Radioactive constituents were present at high concentrations in about 12 percent and at moderate levels in 17 percent of the study area. Gross-alpha radioactivity was the radiochemical constituent detected at moderate and high concentrations most frequently.

Nutrients are naturally present at low concentrations in groundwater; high and moderate concentrations (relative to human-health benchmarks) generally are a result of human activities. Samples were analyzed for five nutrients, of which two (nitrate and nitrite) have human-health benchmarks. Common sources of nutrients, aside from those naturally occurring in soils, include fertilizer applied to crops and landscaping, seepage from septic systems, and human and animal waste. Nitrate was the only nutrient present at elevated concentrations and was at high and moderate concentrations in 7 and 5 percent of the study area, respectively.

\section{Inorganic Constituents and Field Measurements With Non-Health-Based Benchmarks}

(Not included in water-quality overview charts shown on the front page) Some constituents affect the aesthetic properties of water, such as taste, color, and odor, or can create nuisance problems, such as staining and scaling. The benchmarks used for these constituents are non-regulatory secondary maximum contaminant level (SMCL) benchmarks established for public drinking water. Some constituents such as manganese have both human-health benchmarks and SMCLs. Samples were analyzed for 11 constituents that have SMCLs. One or more of these constituents were present at high concentrations in about 63 percent of the study area and at moderate concentrations in about 22 percent.

Total dissolved solids (TDS) concentration is a measure of the salinity of the groundwater based primarily on the concentrations of ions, and all water naturally contains TDS because of the weathering and dissolution of minerals in rocks and sediments. Total dissolved solids concentrations can be high as a result of natural factors or human activities such as road salting and some agricultural activities. Total dissolved solids were present at high and moderate concentrations relative to the SMCL in 48 and 34 percent the study area, respectively.

Anoxic conditions in groundwater (low concentrations of dissolved oxygen) can result in the release of naturally occurring iron and manganese from minerals into groundwater. Iron and manganese were present at high concentrations relative to the SMCL in about 27 and 36 percent of the study area, respectively.

Groundwater $\mathrm{pH}$ has an SMCL range of 6.5 to 8.5. In the Stream Valley aquifers, $\mathrm{pH}$ was less than or greater than the SMCL in about 2 percent of the study area. 


\section{Results: Groundwater Quality at the Depth Zone Used for Public Supply in the Stream Valley Aquifers}

\section{ORGANIC CONSTITUENTS}

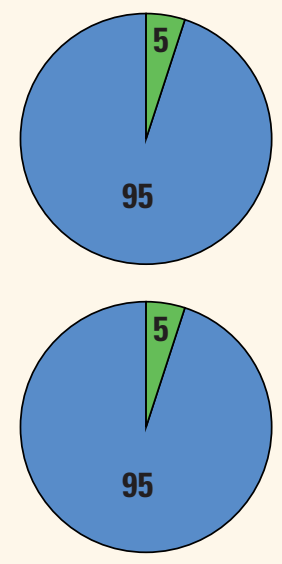

\section{Volatile Organic Compounds With Human-Health Benchmarks}

VOCs

Volatile organic compounds (VOCs) are present in many household, commercial, industrial, and agricultural products and are characterized by their tendency to volatilize (evaporate) into the air. Samples were analyzed for 85 VOCs, of which 51 have human-health benchmarks. Volatile organic compounds were not detected at high concentrations; however, two solvents and the disinfection byproduct chloroform were detected at moderate concentrations in about 5 percent of the study area.

\section{Pesticides With Human-Health Benchmarks}

\section{Pesticides}

Pesticides, including herbicides, insecticides, and fumigants, are applied to crops, gardens and lawns, around buildings, and along roads to help control unwanted vegetation (weeds), insects, fungi, and other pests. Samples were analyzed for 225 pesticide compounds (pesticides and their breakdown products), of which 119 have human-health benchmarks. Pesticide compounds were detected at low concentrations throughout much of the study area. Atrazine and one of its breakdown products were present at moderate concentrations in 5 percent of the study area.

\section{BENCHMARKS FOR EVALUATING GROUNDWATER QUALITY}

The USGS NAWQA Project uses benchmarks established for drinking water to provide context for evaluating the quality of untreated groundwater. The quality of water received by customers is likely different because after withdrawal, groundwater usually is treated prior to delivery. Federal regulatory benchmarks for protecting human health are used for this evaluation of water quality when available. Otherwise, non-regulatory human-health benchmarks and non-regulatory aesthetic benchmarks are used. Not all analyzed constituents have associated benchmarks and thus are not considered in this context. Out of 55 inorganic constituents and properties and 317 organic constituents analyzed, 24 and 157, respectively, have human-health benchmarks.

Concentrations are considered high if they are greater than a human-health benchmark (Norman and others, 2018) or SMCL. For inorganic constituents, concentrations are moderate if they are greater than one-half of a benchmark. For organic constituents, concentrations are moderate if they are greater than one-tenth of a benchmark; this lower threshold was used because organic constituents are generally less prevalent and have smaller concentrations relative to benchmarks than inorganic constituents (Toccalino and others, 2004).

\section{Benchmark Type and Value for Selected Constituents}

This table presents benchmarks for those constituents detected at high concentrations in the Stream Valley aquifers. Benchmark types are regulatory U.S. Environmental Protection Agency (EPA) maximum contaminant levels (MCLs; U.S. Environmental Protection Agency, 2020a), non-regulatory health-based screening levels (HBSLs; Norman and others, 2018), and non-regulatory EPA secondary maximum contaminant levels (SMCLs; U.S. Environmental Protection Agency, 2020b).

$[\mu \mathrm{g} / \mathrm{L}$, microgram per liter; $\mathrm{mg} / \mathrm{L}$, milligram per liter; $\mathrm{pCi} / \mathrm{L}$, picocurie per liter]

\begin{tabular}{|c|c|c|c|c|c|}
\hline \multirow{2}{*}{ Constituent } & \multicolumn{2}{|c|}{ Benchmark } & \multirow{2}{*}{ Constituent } & \multicolumn{2}{|c|}{ Benchmark } \\
\hline & Type & Value & & Type & Value \\
\hline Arsenic & MCL & $10 \mu \mathrm{g} / \mathrm{L}$ & Manganese & HBSL & $300 \mu \mathrm{g} / \mathrm{L}$ \\
\hline Fluoride & MCL & $4 \mathrm{mg} / \mathrm{L}$ & Molybdenum & HBSL & $30 \mu \mathrm{g} / \mathrm{L}$ \\
\hline Gross-alpha activity & MCL & $15 \mathrm{pCi} / \mathrm{L}$ & Cobalt & HBSL & $2 \mu \mathrm{g} / \mathrm{L}$ \\
\hline Nitrate as nitrogen & MCL & $10 \mathrm{mg} / \mathrm{L}$ & Chloride & SMCL & $250 \mathrm{mg} / \mathrm{L}$ \\
\hline Radium-226 and 228 & MCL & $5 \mathrm{pCi} / \mathrm{L}$ & Iron & SMCL & $300 \mu \mathrm{g} / \mathrm{L}$ \\
\hline Radon & MCL & $4,000 \mathrm{pCi} / \mathrm{L}$ & Total dissolved solids (TDS) & SMCL & $500 \mathrm{mg} / \mathrm{L}$ \\
\hline Selenium & MCL & $50 \mu \mathrm{g} / \mathrm{L}$ & Sulfate & SMCL & $250 \mathrm{mg} / \mathrm{L}$ \\
\hline Uranium & MCL & $30 \mu \mathrm{g} / \mathrm{L}$ & Fluoride & SMCL & $2 \mathrm{mg} / \mathrm{L}$ \\
\hline Gross-beta activity & Screening Level & $50 \mathrm{pCi} / \mathrm{L}$ & Manganese & SMCL & $50 \mu \mathrm{g} / \mathrm{L}$ \\
\hline Iron & HBSL & $4,000 \mu \mathrm{g} / \mathrm{L}$ & $\mathrm{pH}$ & SMCL & $6.5-8.5$ \\
\hline
\end{tabular}

\section{PERCENTAGE OF STUDY AREA}

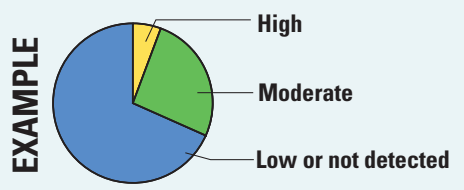

Values are a percentage of the study area with concentrations in the three specified categories. Percentages might not sum to 100 because of rounding. 


\section{Moderate to High Arsenic Concentrations Were Common}

Elevated (greater than $10 \mathrm{ug} / \mathrm{L}$ ) dissolved arsenic concentrations have been documented in alluvial aquifers in other areas across the country (Saunders and others, 2005; Sharif and others, 2008) and throughout the world (Ahmed and others, 2004). Results for this study represent another example of primarily Holoceneage alluvial aquifers with elevated arsenic concentrations. About one-third of the study area had moderate or high arsenic concentrations. Moderate and high arsenic concentrations did not have a systematic spatial distribution but were more prevalent at study sites in

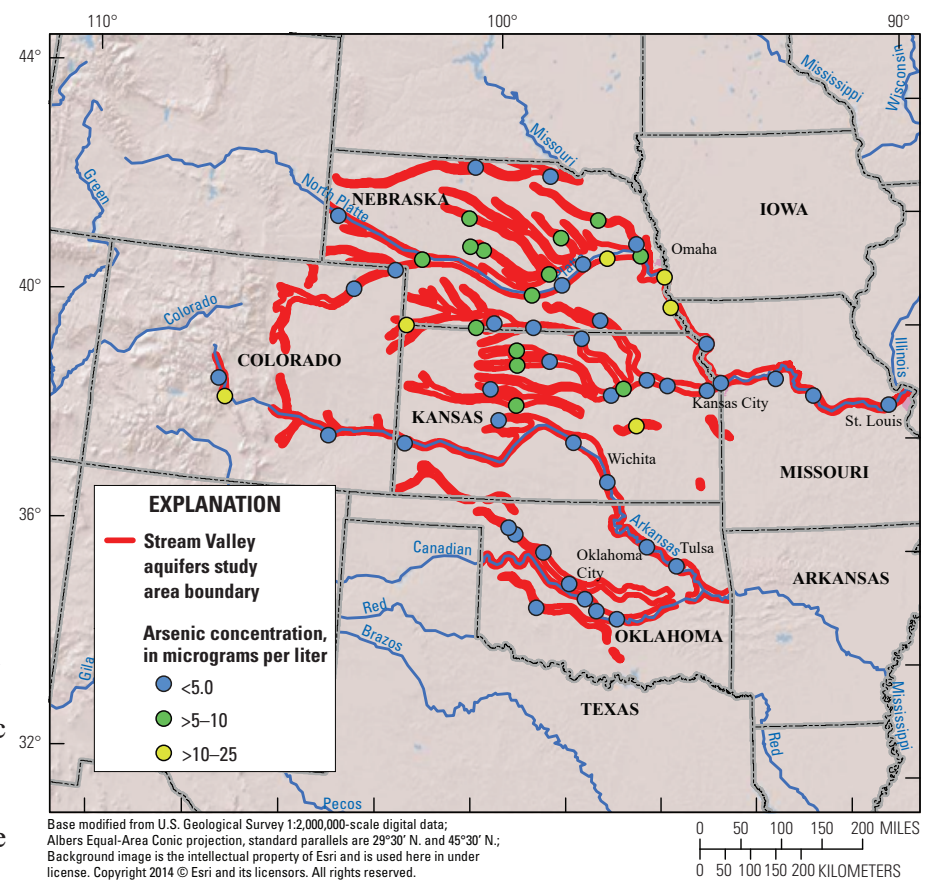
the Missouri River Basin.

Arsenic in groundwater has both natural and anthropogenic sources, but the occurrence in other alluvial aquifer systems generally has been attributed to natural sources and aquifer geochemistry, including factors such as high dissolved organic carbon and iron concentrations (Saunders and others, 2005; Sharif and other, 2008)

\section{By James A. Kingsbury}

\section{SELECTED REFERENCES}

Ahmed, K.M., Bhattacharya, P., Hasan, M.A., Akhter, S.H., Alam, S.M.M., Bhuyian, M.A.H., Imam, M.B., Khan, A.A., Sracek, O., 2004. Arsenic enrichment in ground- water of the alluvial aquifers in Bangladesh: An overview: Applied Geochemistry, v. 19, no. 2, p. 181-200, https://doi.org/10.1016/j.apgeochem.2003.09.006.

Belitz, K., Jurgens B., Landon, M.K., Fram, M.S., and Johnson, T., 2010, Estimation of aquifer scale proportion using equal area grids: Assessment of regional scale groundwater quality: Water Resources Research., v. 46, 14 p., https://doi. org/10.1029/2010WR009321.

Burow, K.R., and Belitz, K., 2014, Groundwater studies-Principal aquifer surveys: U.S. Geological Survey Fact Sheet 2014-3024, 2 p., https://doi.org/10.3133/fs20143024.

DeSimone, L.A., McMahon, P.B., and Rosen, M.R., 2014, The quality of our Nation's waters-Water quality in principal aquifers of the United States, 1991-2010: U.S. Geological Survey Circular 1360, 151 p., https://doi.org/10.3133/cir1360.

Kingsbury, J.A., Bexfield, L.M., Arnold, T., Musgrove, M., Erickson, M.L., Degnan, J.R., Tesoriero, A.J., Lindsey, B.D., and Belitz, K., 2021, Groundwater-quality and select quality-control data from the National Water-Quality Assessment Project, January 2017 through December 2019: U.S. Geological Survey Data Series 1136, 97 p., https://doi.org/10.3133/ds1136.

Kingsbury, J.A., Sharpe, J.B., Bexfield, L.M., Arnold, T.L., Musgrove, M., Erickson, M.L., Degnan, J.R., Tesoriero, A.J., Lindsey, B.D., and Belitz, K., 2020, Datasets of groundwater-quality and select quality-control data from the National Water-Quality Assessment Project, January 2017 through December 2019 (ver. 1.1, January 2021): U.S. Geological Survey data release, https://doi.org/10.5066/P9XATXV1.

Miller, J.A., and Appel, C.L., 1997, Ground water atlas of the United States — segment 3, Kansas, Missouri, Nebraska: U.S. Geological Survey Hydrologic Atlas no. HA-730D, accessed December 12, 2017, at http://pubs.er.usgs.gov/publication/ ha730D.

Norman, J.E., Toccalino, P.L., and Morman, S.A., 2018, Health-based screening levels for evaluating water-quality data (2d ed.): U.S. Geological Survey National Water-Quality Assessment Program web page, https://doi.org/10.5066/F71C1TWP.

Ryder, P.D., 1996, Ground water atlas of the United States - segment 4, Oklahoma, Texas: U.S. Geological Survey Hydrologic Atlas no. HA-730E, accessed December 12, 2017, at http://pubs.er.usgs.gov/publication/ha730E.

Sargent, B.P., Maupin, M.A., and Hinkle, S.R., 2008, Estimated withdrawals from stream-valley aquifers and refined estimated withdrawals from selected aquifers in the United States, 2000: U.S. Geological Survey Scientific Investigations Report 2008-5003, 71 p., https://doi.org/10.3133/sir20085003.

Saunders, J.A., Lee, M.-K., Uddin, A., Mohammad, S., Wilkin, R.T., Fayek, M., and Korte, N.E., 2005, Natural arsenic contamination of Holocene alluvial aquifers by linked tectonic, weathering, and microbial processes: Geochemistry, Geophysics, Geosystems, v. 6, no. 4, p. Q04006, https://doi.org/10.1029/2004GC000803.

Sharif, M.U., Davis, R.K., Steele, K.F., Kim, B., Hays, P.D., Kresse, T.M., and Fazio, J.A., 2008, Distribution and variability of redox zones controlling spatial variability of arsenic in the Mississippi River Valley alluvial aquifer, southeast Arkansas: Journal of Contaminant Hydrology, v. 99, p. 49-67, https://doi.org/10.1016/j.jconhyd.2008.03.001.

Toccalino, P.L., Norman, J.E., Phillips, R.H., Kauffman, L.J., Stackelberg, P.E., Nowell, L.H., Krietzman, S.J., and Post, G.B. 2004, Application of health-based screening levels to ground-water quality data in a state-scale pilot effort: U.S. Geological Survey Scientific Investigations Report 2004-5174, 64 p., https://doi.org/10.3133/sir20045174.

U.S. Environmental Protection Agency, 2020a, National primary drinking water regulations: U.S. Environmental Protection Agency web page, accessed March 2020 at https://www.epa.gov/ground-water-and-drinking-water/national-primary-drinkingwater-regulations.

U.S. Environmental Protection Agency, 2020b, Secondary drinking water standards - Guidance for nuisance chemicals: U.S. Environmental Protection Agency web page, accessed March 2020 at https://www.epa.gov/sdwa/secondary-drinking-waterstandards-guidance-nuisance-chemicals.

\section{Principal Aquifer Studies}

The USGS NAWQA Project

has been assessing the quality of groundwater since 1991. The NAWQA studies include Land Use Studies (LUS), Major Aquifer Studies (MAS), and Principal Aquifer Studies (PAS). These three study types are based on the sampling of networks of wells distributed across an area of interest. The LUS networks typically consist of observation wells that are relatively shallow; MAS networks typically consist of domestic-supply wells that are intermediate in depth; and PAS networks typically consist of public-supply wells that are relatively deep. A national synthesis of shallow and intermediate depth groundwater quality was reported by DeSimone and others (2014). This fact sheet provides a summary of PAS data for 59 public-supply wells sampled in 2018 in the Stream Valley aquifers principal aquifer (data available in Kingsbury and others, 2020).

The PAS assessments like this one allow for the comparison of constituent concentrations in untreated groundwater with benchmarks established for the protection of human health and for aesthetic qualities for drinking water and provide a basis for comparison of groundwater quality among principal aquifers.

The data collected by NAWQA Project include chemical analyses generally not available as part of regulatory compliance monitoring, including measurements at concentrations much lower than human-health benchmarks and measurement of constituents that can be used to trace the sources and movement of groundwater.

\section{For more information}

Technical reports and hydrologic data collected for the USGS NAWQA Project may be obtained from

\section{Program Coordinator}

U.S. Geological Survey

Water Availability and Use Science Program

Email: wausp-info@usgs.gov WEB: https://water.usgs.gov/nawqa 